Article

\title{
Biomass Pyrolysis Solids as Reducing Agents: Comparison with Commercial Reducing Agents
}

\author{
Aitziber Adrados *, Isabel De Marco ${ }^{\dagger}$, Alexander López-Urionabarrenechea ${ }^{\dagger}$, Jon Solar $^{\dagger}$, \\ Blanca M. Caballero ${ }^{\dagger}$ and Naia Gastelu ${ }^{\dagger}$
}

Received: 22 October 2015; Accepted: 16 December 2015; Published: 23 December 2015

Academic Editor: Rafael Luque

Department of Environmental and Chemical Engineering, University of the Basque Country UPV/EHU, Bilbao 48013, Spain; isabel.demarco@ehu.eus (I.D.M.); alex.lopez@ehu.eus (A.L.-U.); jon.solar@ehu.eus (J.S.); blancamaria.caballero@ehu.eus (B.M.C.); naia.gastelu@ehu.eus (N.G.)

* Correspondence: aitziber.adrados@ehu.eus; Tel.: +34-94-601-7297

+ These authors contributed equally to this work.

\begin{abstract}
Biomass is one of the most suitable options to be used as renewable energy source due to its extensive availability and its contribution to reduce greenhouse gas emissions. Pyrolysis of lignocellulosic biomass under appropriate conditions (slow heating rate and high temperatures) can produce a quality solid product, which could be applicable to several metallurgical processes as reducing agent (biocoke or bioreducer). Two woody biomass samples (olives and eucalyptus) were pyrolyzed to produce biocoke. These biocokes were characterized by means of proximate and ultimate analysis, real density, specific surface area, and porosity and were compared with three commercial reducing agents. Finally, reactivity tests were performed both with the biocokes and with the commercial reducing agents. Bioreducers have lower ash and sulfur contents than commercial reducers, higher surface area and porosity, and consequently, much higher reactivity. Bioreducers are not appropriate to be used as top burden in blast furnaces, but they can be used as fuel and reducing agent either tuyére injected at the lower part of the blast furnace or in non-ferrous metallurgical processes where no mechanical strength is needed as, for example, in rotary kilns.
\end{abstract}

Keywords: biomass; biocoke; bioreducer; slow pyrolysis

\section{Introduction}

The metallurgical industry is a great consumer of fossil fuels. It uses great amounts of coke as fuel and reducing agent [1-3], with the consequence of large emissions of carbon dioxide $\left(\mathrm{CO}_{2}\right)$, the primary greenhouse gas emitted by human activities [4].

International concerns about climate change are leading to a decrease in $\mathrm{CO}_{2}$ emissions. Recently, the Intergovernmental Panel on Climate Change (IPCC) identified in the Fifth Assessment Report the world's carbon budget [5], i.e., the amount of $\mathrm{CO}_{2}$ the world can emit while still having a likely chance of limiting global temperature rise to $2{ }^{\circ} \mathrm{C}$ above pre-industrial levels. The $2{ }^{\circ} \mathrm{C}$ target was adopted by the countries within the United Nations Framework Convention on Climate Change (UNFCC) [6]. The international scientific community estimates this budget to be 1 trillion tons of carbon. In 2011, $52 \%$ of the budget had already been burned, and it is estimated that the budget will be exceeded before the end of 2045 if emissions rates continue with the same tendency [5]. To avoid this, new ideas and concepts must be developed by the industry.

The production of reducing agents (biocokes or bioreducers) by pyrolysis of biomass is one of these ideas and a step further in the reduction of the environmental impact of industry.

The key factor in the production of coke from biomass is the fact that biomass derived products and processes imply neutral $\mathrm{CO}_{2}$ emissions. Biomass absorbs atmospheric $\mathrm{CO}_{2}$ while it grows and 
returns it into the atmosphere when it is burned, all in a relatively short amount of time. Because of this, biomass utilization creates a closed loop carbon cycle. The substitution of fossil fuel coke by more environmentally friendly biocokes is of the most interest. For this reason, the objective of this paper is to compare the properties of biocokes obtained by pyrolysis of lignocellulosic biomass with those of typical commercial reducing agents used in non-ferrous processes, in order to evaluate the suitability of the biocokes as reducing agents.

The production of biocoke from biomass is not new; in fact it is the update and modernization of the traditional process of obtaining charcoal from wood. In recent years the effects of the type of biomass and of the operating parameters used on the properties of the obtained char have been investigated [7-12].

The production of a coke-like product from biomass requires more demanding process conditions than the traditional method, since traditional coke is a macroporous carbon material produced by carbonization of coals or coal blends of specific rank and characteristics [13]. In other words, to obtain a coke-like product from wood, the carbonization of wood followed by the carbonization of the resultant coal must occur in the same process. Griessacher and Antrekowitsch [14] and Griessacher, et al. [15] reported that a coke-like product can be obtained by slow pyrolysis of wood at high temperature $\left(700-1000^{\circ} \mathrm{C}\right)$.

One of the most important influencing parameter of the slow pyrolysis (carbonization) process is temperature. It is well known that by increasing temperature the amount of volatile components in the coal decreases and therefore the carbon content in the coal becomes higher reaching the carbon content of cokes [16]. Heating rate is also a very important parameter that influences the amount and characteristics of pyrolysis products. It has been reported [17] that a higher char yield is obtained with decreasing heating rate, since the slow emerging wood products have more time to react and carbonize. It may be expected that the lower the heating rate, the lower the char porosity and reactivity since the volatile products from the biomass emerge more slowly. The objective of the present work was to obtain solids from biomass useful as reducing agents for metallurgical processes (biocoke or bioreducers). Therefore, high temperatures and slow heating rates were used. On the other hand, the feedstock material is a key factor for the production of biocoke, and therefore, two woody biomass samples, olive tree cuttings, and eucalyptus, were used in this study. It is well known that woody biomass is the best biomass feedstock for coke production.

In order to evaluate the suitability of the pyrolysis solids as alternative reducing agents in metallurgy, it is important to characterize the biocokes, by determining their chemical and physical properties, and also their reactivity with $\mathrm{CO}_{2}$. There are standardized reactivity measurement methods like the ASTM D 5341-99 standard [18,19] which was developed from the Nippon Steel Corporation (NSC) test procedure, and has been traditionally used for evaluating the quality of coal derived metallurgical cokes.

In this study, characterization and reactivity measurements of the biocokes obtained in pyrolysis experiments as well as of three commercial reducing agents used in metallurgical processes were carried out.

\section{Materials and Methods}

\subsection{Materials}

Two different biomass samples were pyrolyzed: an abundant waste woody biomass sample, olive tree cuttings, coming from the South of Spain and an extensive energy crop, eucalyptus (camaldulensis) wood, coming from South America.

The olive tree cuttings sample was selected since the major woody crop in Spain is olive. In Spain there are 2,605,252 ha of olive groves [20]. One hectare of olive groves generates about three tons of pruning residues [21] which means 7,815,756 tons of branches and leaves per year, most of which are illegally burnt or left on the ground partially for recirculation of nutrients.

On the other hand, the eucalyptus family was selected as an extensive energy crop because of its fast growth rate and abundance, especially in South America. It is worth mentioning that Eucalyptus 
occupies $70 \%$ of the 950,000 ha of the forest plantation in Uruguay and $60 \%$ of the 5,500,000 ha of forest plantation in Brazil.

The composition of both biomass samples is presented in Table 1.

Table 1. Proximate, ultimate and constituents analyses of the original pyrolyzed biomass samples.

\begin{tabular}{|c|c|c|c|}
\hline \multicolumn{2}{|c|}{ (Weight \%) } & \multirow{2}{*}{$\begin{array}{c}\text { Olives } \\
8.8\end{array}$} & \multirow{2}{*}{$\frac{\text { Eucalyptus }}{11.4}$} \\
\hline \multirow{4}{*}{ Proximate analysis (ar) ${ }^{a}$} & Moisture & & \\
\hline & Volatile matter & 74.3 & 69.7 \\
\hline & Ash & 2.1 & 2.1 \\
\hline & Fixed carbon ${ }^{c}$ & 14.8 & 16.8 \\
\hline \multirow{5}{*}{ Ultimate analysis (daf) ${ }^{b}$} & $\mathrm{C}$ & 49.4 & 52.7 \\
\hline & $\mathrm{H}$ & 6.2 & 3.7 \\
\hline & $\mathrm{N}$ & 0.3 & 0.1 \\
\hline & $\mathrm{S}$ & $<0.1$ & $<0.1$ \\
\hline & Others (mainly O) ${ }^{\mathrm{c}}$ & 44.1 & 43.5 \\
\hline \multicolumn{2}{|c|}{$\mathrm{HHV}(\mathrm{ar})^{\mathrm{a}}\left(\mathrm{MJ} \cdot \mathrm{kg}^{-1}\right)$} & 16.1 & 16.6 \\
\hline \multicolumn{2}{|c|}{$\mathrm{H} / \mathrm{C}$ atomic ratio } & 1.5 & 0.8 \\
\hline \multicolumn{2}{|c|}{$\mathrm{C} / \mathrm{N}$ weight ratio } & 146.7 & 455.0 \\
\hline \multirow{5}{*}{ Constituents (daf) ${ }^{b}$} & Extractives & 12.1 & 8.3 \\
\hline & Cellulose & 32.9 & 38.5 \\
\hline & Hemicellulose & 19.7 & 13.6 \\
\hline & Lignin & 18.3 & 29.3 \\
\hline & Others $^{c}$ & 15.7 & 10.3 \\
\hline
\end{tabular}

${ }^{a}$ ar: as received basis; ${ }^{b}$ daf: dry and ash free basis; ${ }^{c}$ By difference.

It can be observed that the eucalyptus and the olive tree cuttings samples are quite different. The eucalyptus sample has more moisture, less volatiles and more fixed carbon than the olive sample. Concerning the ultimate analysis, the eucalyptus sample has more $\mathrm{C} \%$, less $\mathrm{H} \%$ and less $\mathrm{N} \%$ than the olives sample, and as a consequence has lower $\mathrm{H} / \mathrm{C}$ and higher $\mathrm{C} / \mathrm{N}$ ratios than the olives sample. The lower the $\mathrm{C} / \mathrm{N}$ ratio, the higher the degradability of the organic matter, so the results indicate that eucalyptus is more resistant to biodegradation than the olives sample.

Concerning the constituents' composition, Table 1 shows that the eucalyptus sample has greater lignin content and lower hemicellulose content than the olives sample. With respect to extractives, it has been reported that they are more abundant in bark than in inner wood parts [22]. This justifies the fact that the eucalyptus sample, which has a lower bark/wood ratio than the olives sample, has less extractives.

Regarding the higher heating value of the biomass samples, there are no significant differences between them. Both values are around $16.4 \mathrm{MJ} \cdot \mathrm{kg}^{-1}$, which are heating values comparable to those of low quality fuels like lignites $\left(\approx 16 \mathrm{MJ} \cdot \mathrm{kg}^{-1}\right)$.

In order to compare the properties of the pyrolitically produced biocokes, three commercial reducers provided by Befesa Zinc Aser S.A., an Electric Arc Furnace dust recycling company, located in Erandio (Biscay, Spain) were analyzed and tested: a metallurgical coke, a petroleum coke, and an anthracite. The characterization of these commercial reducers is presented in Table 5, and is discussed and compared to biocoke characteristics in Section 3.1.

\subsection{Experimental Procedure}

\subsubsection{Pyrolysis Experiments}

Pyrolysis experiments with biomass samples were carried out using two reactors connected in series: a first 3.5 L semi-batch non-stirred pyrolysis reactor where $100 \mathrm{~g}$ of biomass were pyrolyzed at $600{ }^{\circ} \mathrm{C}$ and $750^{\circ} \mathrm{C}$ and with heating rates of 3,15 , and $20^{\circ} \mathrm{C} \cdot \mathrm{min}^{-1}$, and a second tubular reactor 
where pyrolysis vapors were thermally upgraded at $900{ }^{\circ} \mathrm{C}$. The vapors were swept with $1 \mathrm{~L} \cdot \mathrm{min}^{-1}$ of nitrogen $\left(\mathrm{N}_{2}\right)$ to a water cooled glass condensing system, where liquids were collected, followed by an activated carbon column (to retain the possible small particles that the gases could transport) before they were collected in plastic gas bags. The biocokes produced remained in the first reactor. The solid and liquid yields were determined by weight difference, while gas yield was calculated by difference to 100. Each yield presented in this paper is the mean value of the data obtained in two equivalent experiments which differed by less than three points. A flow sheet of the experimental setup used can be seen in Adrados, et al. [23].

\subsubsection{Reactivity Experiments}

The procedure used for the reactivity experiments is based on the ASTM D 5341-99 standard [18]. However, to meet the specifications of this standard, specific large equipment and a great amount of sample $(250 \mathrm{~g})$ is required. Since neither of them was available, an adaptation of the ASTM method had to be carried out trying to keep the different operational parameters as close as possible to the specifications of the standard. This ASTM standard is based on the Boudouard reaction $\left(\mathrm{C}+\mathrm{CO}_{2} \leftrightarrow \mathrm{CO}\right)$, in which carbon reacts with $\mathrm{CO}_{2}$ and forms carbon monoxide (CO). Depending on the reactivity of the material, the quantity of carbon consumed is variable.

Two parameters were determined in the reactivity tests: the so called coke reactivity index (CRI) and the $R$ factor (1) and (2).

$$
\begin{gathered}
\text { CRI }(\%)=\frac{\text { initial sample weight }- \text { final weight }}{\text { initial sample weight }} \times 100 \\
R \text { factor }(\%)=\frac{\mathrm{CO}}{\mathrm{CO}_{2}+\mathrm{CO} / 2} \times 100
\end{gathered}
$$

The CRI is the mass weight loss after the treatment of the sample with $\mathrm{CO}_{2}$ or the degree of conversion ( $\mathrm{wt} \%$ ) and the $\mathrm{R}$ factor is the amount of $\mathrm{CO}$ in the gas stream after reaction with respect to the total amount of $\mathrm{CO}_{2}$ used in the test ( $\mathrm{vol} \%$ ). High values of both parameters indicate high reactivity of the sample.

The reactivity experiments with the biocokes and the commercial reducers were performed in the same plant used for pyrolysis experiments but adapted for the reactivity tests. In this case, the installation was composed of four units connected in series: (1) a first 3.5 L empty preheater, where the feed gases were pre-heated to $800{ }^{\circ} \mathrm{C}$; (2) a second tubular reactor where a fixed bed of the biocoke was placed; (3) a dust trap (empty bubbler) where the small solid particles swept by the $\mathrm{CO}_{2}$ flow were retained; and (4) Tedlar plastic bags where the gases of the whole test were collected. All the apparatus were connected with silicone tubing.

The tubular reactor used for the reactivity experiments was $2.54 \mathrm{~cm}$ in diameter and $60 \mathrm{~cm}$ long, and was made of INCONEL alloy 601, a material able to work at temperatures as high as $1200^{\circ} \mathrm{C}$, while in the pyrolysis experiments a 309 stainless steel tubular reactor was used.

The system was purged with $\mathrm{N}_{2}$ in order to remove the oxygen $\left(\mathrm{O}_{2}\right)$ originally contained in the installation. The reactor's furnace was warmed up to $1000{ }^{\circ} \mathrm{C}$, and then a $\mathrm{CO}_{2}$ gas flow of 1375 or $750 \mathrm{~mL} \cdot \mathrm{min}^{-1}$ was passed through the sample for $2 \mathrm{~h}$. The charcoal reacts with $\mathrm{CO}_{2}$, producing $\mathrm{CO}$. The gases generated in the whole run were continuously collected in plastic bags, to be immediately analyzed off-line with a gas chromatograph connected to a thermal conductivity and a flame ionization detector (GC-TCD, FID). After $2 \mathrm{~h}$, the input gas stream was again swapped to $\mathrm{N}_{2}$ and the furnace was cooled down.

\subsection{Analytical Techniques}

The initial feedstock, the solid pyrolysis products, and the commercial reducers were characterized using the following analytical techniques. The proximate analysis was determined 
by thermogravimetry according to D3173-85 and D3174-82 ASTM standards by means of a LECO TGA-500, and the elemental composition was determined with a LECO TruSpec CHN and a TruSpec $\mathrm{S}$ analyzer. The higher heating value (HHV) was determined using a LECO AC-500 automatic calorimetric bomb.

Real density was determined in an AccuPyc 1330T Micromeritics equipment. All the samples were degassed at $120^{\circ} \mathrm{C}$ for $18 \mathrm{~h}$ before the analyses. The surface areas and the porosity properties were measured via $\mathrm{CO}_{2}$ adsorption at $0{ }^{\circ} \mathrm{C}$ using a surface area analyzer, Quantachrome Nova 4200 apparatus. $\mathrm{CO}_{2}$ adsorption is a widely used method to analyze materials with narrow micropores, as is the case of carbonized materials. The isotherms were analyzed using the Dubinin Radushkevich equation (DR) for calculating the micropores volume $\left(\mathrm{cm}^{3} \cdot \mathrm{g}^{-1}\right)$ and the equivalent micropore surface area $\left(\mathrm{m}^{2} \cdot \mathrm{g}^{-1}\right)$. The pore size distribution was calculated using the Non Local Density Functional Theory (NL DFT) available in the software of the equipment.

\section{Results and Discussion}

\subsection{Yields, and Proximate and Ultimate Analysis of Pyrolysis Solids}

The characteristics of the solids obtained in the pyrolysis experiments can be influenced by the operating conditions of the first pyrolysis reactor. Olive tree cuttings and eucalyptus were pyrolyzed at different temperatures and heating rates, therefore, several biochars were obtained. Their yields and characterization are presented in Tables 2 and 3.

Table 2. Proximate and ultimate analyses of the pyrolysis solids obtained at different temperatures $\left(20^{\circ} \mathrm{C} \cdot \min ^{-1}\right)$.

\begin{tabular}{|c|c|c|c|c|c|}
\hline \multirow{2}{*}{\multicolumn{2}{|c|}{ (Weight \%) }} & \multicolumn{2}{|c|}{ Olives } & \multicolumn{2}{|c|}{ Eucalyptus } \\
\hline & & $600{ }^{\circ} \mathrm{C}$ & $750^{\circ} \mathrm{C}$ & $600{ }^{\circ} \mathrm{C}$ & $750^{\circ} \mathrm{C}$ \\
\hline \multicolumn{2}{|c|}{ Solid yields } & 22.9 & 21.3 & 22.4 & 22.9 \\
\hline \multirow{4}{*}{ Proximate analysis (ap) ${ }^{a}$} & Moisture & 2.0 & 1.7 & 2.2 & 1.4 \\
\hline & Volatile matter & 11.8 & 10.0 & 12.0 & 8.6 \\
\hline & Ash & 9.5 & 9.2 & 5.9 & 6.2 \\
\hline & Fixed Carbon $^{\mathrm{c}}$ & 76.7 & 79.1 & 79.9 & 83.8 \\
\hline \multirow{4}{*}{ Ultimate analysis (daf) ${ }^{b}$} & $\mathrm{C}$ & 86.0 & 94.5 & 88.0 & 90.1 \\
\hline & $\mathrm{H}$ & 2.1 & 0.9 & 1.4 & 0.8 \\
\hline & $\mathrm{N}$ & 0.8 & 1.2 & 0.6 & 0.6 \\
\hline & Others (mainly O) ${ }^{c}$ & 11.1 & 3.4 & 10.0 & 8.5 \\
\hline \multicolumn{2}{|c|}{$\mathrm{HHV}(\mathrm{ap})^{\mathrm{a}}\left(\mathrm{MJ} \mathrm{kg}^{-1}\right)$} & 30.8 & 28.8 & 31.6 & 31.0 \\
\hline
\end{tabular}

${ }^{\mathrm{a}}$ ap: as produced basis; ${ }^{\mathrm{b}}$ daf: dry and ash free basis; ${ }^{\mathrm{c}}$ By difference.

Table 3. Characteristics of the pyrolysis solids obtained at different heating rates $\left(750{ }^{\circ} \mathrm{C}\right)$.

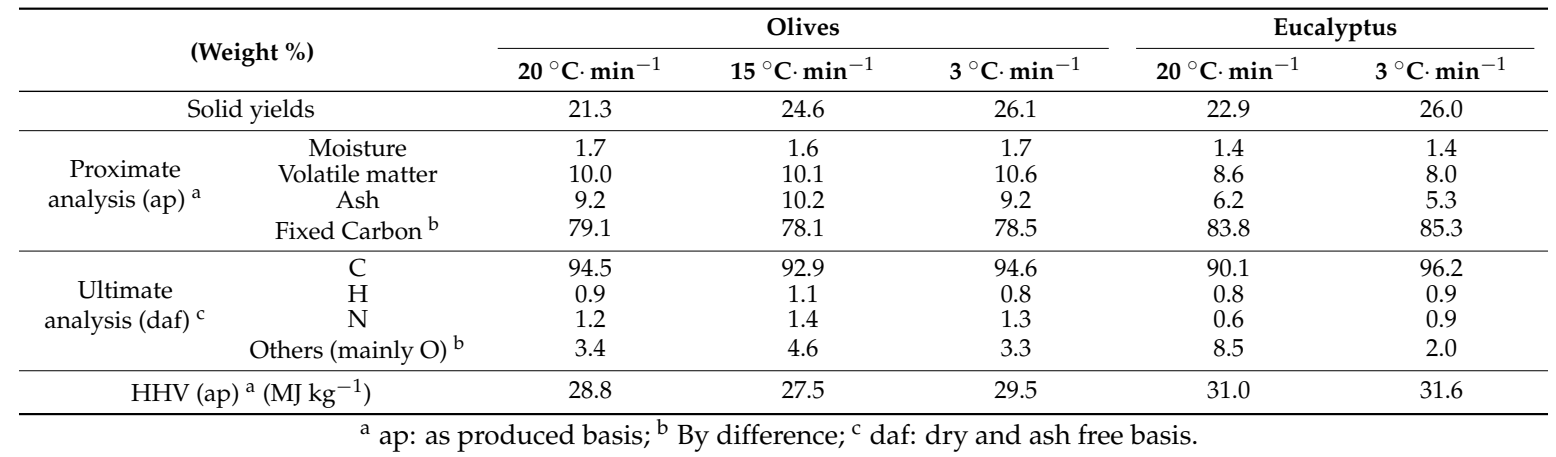

Taking a look at the solid yields, in Table 2 it can be seen that temperature has not much influence. However, Table 3 shows an influence of the heating rate: the lower the heating rate, the higher the solid yield. These results are in agreement with the results obtained by other authors [24,25]. The pyrolysis 
solid yields are in the range of $21-23 \mathrm{wt} \%$ at $20{ }^{\circ} \mathrm{C} \cdot \mathrm{min}^{-1}$ and $26 \mathrm{wt} \%$ when the lowest heating rate is used. Therefore the reduction of heating rate has the beneficial effect of increasing the pyrolysis solids yields. Liquid and gas yields obtained in these pyrolysis experiments can be found in [26].

Pyrolysis solids are mainly composed of carbon, with elemental carbon contents around $90 \mathrm{wt} \%$. The moisture content is rather low $(\approx 1.7 \mathrm{wt} \%)$, the volatiles content is quite low $(\approx 11 \mathrm{wt} \%)$ and the ash content is around 9 and $6 \mathrm{wt} \%$ for olives and eucalyptus samples respectively.

It is well known that the higher the fixed carbon and the lower the volatile matter content, the better is the quality of metallurgical reducing agents. Table 2 shows that the fixed and elemental carbon contents of the biocokes of both samples are higher while the volatile matter is lower when the higher pyrolysis temperature $\left(750^{\circ} \mathrm{C}\right)$ is used. Similar tendencies regarding the effect of temperature in the fixed carbon and volatile matter contents of pyrolysis solids have been reported in the literature [27].

Table 3 shows that there is no influence of heating rate on the composition of pyrolysis solids. Although it is a well-known fact that decreasing heating rates intensifies the carbonization process giving rise to carbon-richer products, this tendency is not observed in the results of Table 3 . The reason for this may be that $20^{\circ} \mathrm{C} \cdot \mathrm{min}^{-1}$ is a heating rate slow enough to produce a well carbonized product at $750{ }^{\circ} \mathrm{C}$, so that slower heating rates do not further promote carbonization at such temperature.

Regarding the HHV of the pyrolysis solids it can be seen that it is rather high $\left(\approx 30 \mathrm{MJ} \cdot \mathrm{kg}^{-1}\right)$ which is in the range of the HHV of commonly used solid fossil fuels, such as bituminous coals [28].

In view of the characteristics of biomass derived pyrolysis solids, many potential applications for them can be proposed. They can be used as rather good quality solid fuel (high HHV, low pollutants (S, N) content and low ash contents compared to fossil fuels), or as sorbent material provided that it is firstly activated, or as soil amendment agent. However, the application proposed in this work is as reducing agent for metallurgical purposes. For this reason, the three previously mentioned commercial reducing agents (metallurgical coke, petroleum coke, and anthracite), used for $\mathrm{Zn}$ reduction in rotary kilns by Befesa Zinc Aser S.A. company, were characterized. The detailed specifications that Befesa Zinc Aser S.A. requires from their providers of reducing agents are presented in Table 4 . The specifications on dry basis, which are also included in the table, have been calculated considering that the moisture content is $20 \mathrm{wt} \%$, which is as the table shows, the maximum allowable moisture specified by Befesa; these data on dry basis would be the permitted values if the sample did not contain moisture and enable coke samples to be compared regardless of their moisture.

Table 4. Quality specifications for commercial reducing agents required by Befesa Zinc Aser S.A. company 2013.

\begin{tabular}{cccc}
\hline Material & Parameter & $\begin{array}{c}\text { Befesa Zinc Aser Technical } \\
\text { Specifications (wt \%) }\end{array}$ & $\begin{array}{c}\text { Specifications on } \\
\text { Dry Basis (wt \%) * }\end{array}$ \\
\hline Granulometry & $\begin{array}{c}<10 \mathrm{~mm}: \leqslant 20 \% \\
<2 \mathrm{~mm}: \leqslant 40 \% \\
\text { on daily sample }\end{array}$ \\
\cline { 2 - 4 } Metallurgical coke & Dry ash & $\leqslant 20 \%$ on monthly sample & $\leqslant$ \\
& Moisture & $\leqslant 20 \%$ on daily sample & - \\
& Volatile matter & $\leqslant 7 \%$ on monthly sample & $\leqslant 8.75 \%$ \\
& Sulfur & $\leqslant 3 \%$ on monthly sample & $\leqslant 3.75 \%$ \\
\hline
\end{tabular}


Table 4. Cont.

\begin{tabular}{cccc}
\hline Material & Parameter & $\begin{array}{c}\text { Befesa Zinc Aser Technical } \\
\text { Specifications (wt \%) }\end{array}$ & $\begin{array}{c}\text { Specifications on } \\
\text { Dry Basis (wt \%) * }\end{array}$ \\
\hline Granulometry & $\begin{array}{c}<\mathrm{mm}:>30 \% \\
\text { Petroleum coke }\end{array}$ & on diary sample & - \\
\cline { 2 - 4 } & Dry ash & $\leqslant 20 \%$ on monthly sample & $\leqslant 20 \%$ \\
Moisture & $\leqslant 20 \%$ on daily sample & - \\
& Volatile matter & $\leqslant 15 \%$ on monthly sample & $\leqslant 18.75 \%$ \\
Sulfur & $\leqslant 3 \%$ on monthly sample & $\leqslant 3.75 \%$ \\
\hline Anthracite & Granulometry & $>10$ mm: $\leqslant 20 \%$ & - \\
& on diary sample & \\
& Dry ash & $\leqslant 20 \%$ on monthly sample & $\leqslant 20 \%$ \\
& Moisture & $\leqslant 20 \%$ on daily sample & - \\
& Volatile matter & $\leqslant 7 \%$ on monthly sample & $\leqslant 8.75 \%$ \\
& Sulfur & $\leqslant 3 \%$ on monthly sample & $\leqslant 3.75 \%$ \\
\hline
\end{tabular}

${ }^{*}$ Calculated considering a moisture content of $20 \mathrm{wt} \%$ (maximum permitted by Befesa).

Table 5 presents the proximate and ultimate analyses of the commercial reducing agents and the biomass-based reducing agents obtained at $3{ }^{\circ} \mathrm{C} \cdot \mathrm{min}^{-1}$ and $750{ }^{\circ} \mathrm{C}$, all on dry basis. For better analysis of the results, the Befesa specifications are included in brackets in Table 5 .

Table 5. Proximate and ultimate analyses of the commercial reducers and the bioreducers $\left(750{ }^{\circ} \mathrm{C}\right.$ and $\left.3^{\circ} \mathrm{C} \cdot \min ^{-1}\right)$.

\begin{tabular}{|c|c|c|c|c|c|c|}
\hline \multirow{2}{*}{\multicolumn{2}{|c|}{ Dry Basis (wt \%) }} & \multicolumn{3}{|c|}{ Commercial Reducers } & \multicolumn{2}{|c|}{ Bioreducers } \\
\hline & & Metallurgical Coke & Petroleum Coke & Anthracite & Olives & Eucalyp. \\
\hline \multicolumn{2}{|c|}{ Moisture } & $11.4(<20)$ & $6.4(<20)$ & $18.0(<20)$ & 1.7 & 1.4 \\
\hline \multirow{3}{*}{$\begin{array}{l}\text { Proximate } \\
\text { analysis }\end{array}$} & Volatile matter & $3.9(<8.75)$ & $10.1(<18.75)$ & $7.2(<8.75)$ & 10.8 & 8.1 \\
\hline & Ash & $12.5(<20)$ & $2.0(<20)$ & $11.2(<20)$ & 9.4 & 5.4 \\
\hline & Fixed carbon * & 83.6 & 87.9 & 81.6 & 79.9 & 86.5 \\
\hline \multirow{5}{*}{$\begin{array}{l}\text { Ultimate } \\
\text { analysis }\end{array}$} & C & 84.4 & 83.5 & 86.6 & 85.6 & 90.9 \\
\hline & $\mathrm{H}$ & 0.5 & 2.8 & 0.6 & 0.8 & 1.0 \\
\hline & $\mathrm{N}$ & 1.0 & 1.3 & 1.0 & 1.2 & 0.8 \\
\hline & S & $0.9(<3.75)$ & $5.6(<3.75)$ & $0.6(<3.75)$ & $<0.05$ & $<0.05$ \\
\hline & Others * & 0.8 & 4.9 & 0.0 & 3.0 & 1.9 \\
\hline \multicolumn{2}{|c|}{$\mathrm{HHV}\left(\mathrm{MJ} \cdot \mathrm{kg}^{-1}\right)$} & 29.3 & 35.9 & 31.1 & 29.5 & 31.6 \\
\hline
\end{tabular}

It is a fact worth mentioning that the commercial reducers have very high moisture contents. Such contents certainly do not correspond to the natural inherent moisture of these materials, and it is most probably accidental moisture incorporated into the samples during their transport and/or storage. As a matter of fact, water drops could be seen in the containers in which the commercial reducers were provided. For this reason, the proximate and ultimate analyses of all the samples are presented in Table 5 on dry basis, in order to more fairly compare the intrinsic properties of the commercial and the biomass derived reducers, regardless of the moisture content.

It has also to be mentioned that although the commercial reducers were provided by Befesa Zinc Aser S.A. itself, one of them (petroleum coke) does not totally fulfill the quality requirements specified by the company, since it contains more sulfur ( $5.6 \mathrm{wt} \%$ ) than that specified in Table $4(<3 \mathrm{wt} \%)$.

Comparing the results of the commercial reducers and the bioreducers, the following advantages of the bioreducers can be mentioned: they have much lower moisture contents than any of the commercial reducers, lower ash contents than the metallurgical coke and the anthracite, and significantly lower sulfur contents than any of the commercial reducers. There is only one specification 
not fulfilled in the bioreducer derived from the olives sample: the volatile content is slightly higher than that specified for metallurgical coke and anthracite, though it does meet, by far, the petroleum coke volatile matter specification.

Therefore, it can be concluded that as far as composition is concerned, the olives and eucalyptus derived bioreducers can replace the commercial reducers in metallurgical processes in rotary kilns with the great advantage of having lower ash and sulfur contents.

\subsection{Real Density, Specific Surface Area, and Porosity Measurements}

Real density, specific surface area, and porosity of the pyrolysis reducers and of the commercial reducers were measured.

The results obtained in the textural characterization of the pyrolysis solids obtained at $20^{\circ} \mathrm{C} \cdot \mathrm{min}^{-1}$ and different pyrolysis temperatures are presented in Figures 1 and 2 and Table 6.

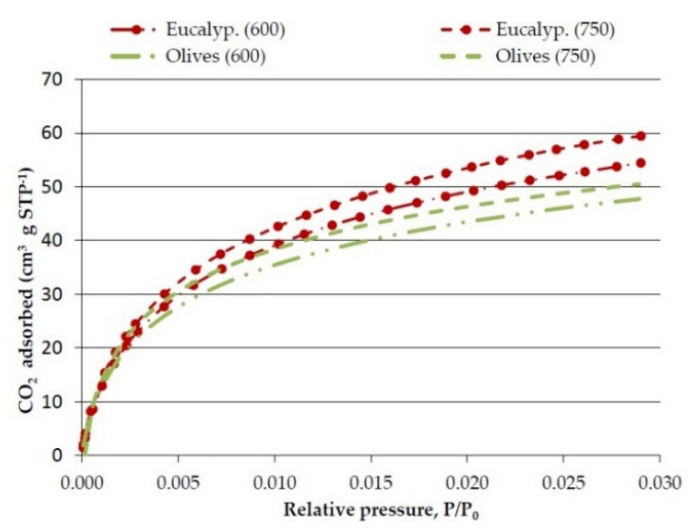

Figure 1. Effect of temperature on $\mathrm{CO}_{2}$ adsorption isotherms of the bioreducers obtained at $20{ }^{\circ} \mathrm{C} \cdot \mathrm{min}^{-1}$ from olives and eucalyptus samples.

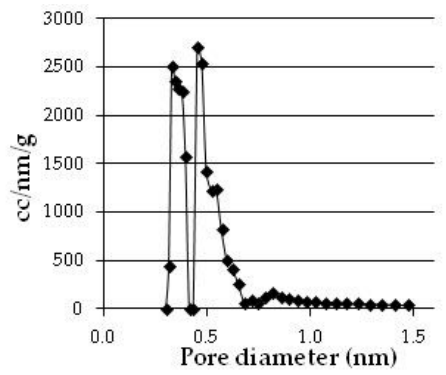

(a)

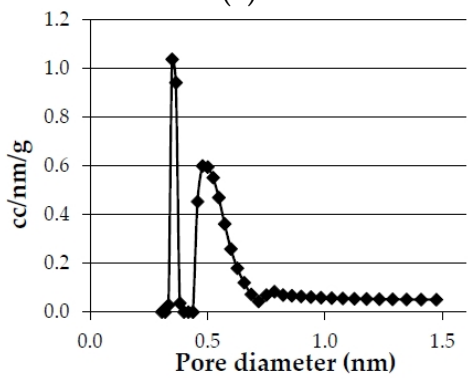

(c)

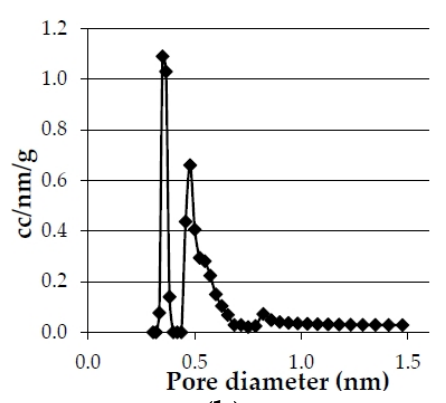

(b)

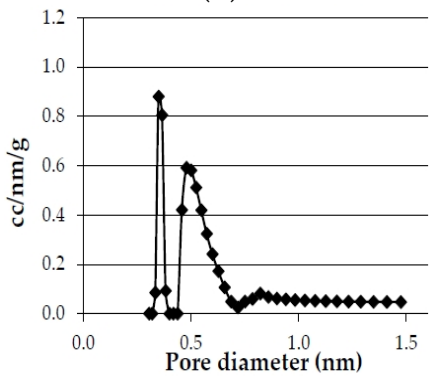

(d)

Figure 2. Effect of temperature in pore size distribution of the bioreducers obtained at $20^{\circ} \mathrm{C} \cdot \mathrm{min}^{-1}$ from olives and eucalyptus samples. (a) Olives $\left(750{ }^{\circ} \mathrm{C}\right)$; (b) Olives $\left(600^{\circ} \mathrm{C}\right)$; (c) Eucalyptus $\left(750^{\circ} \mathrm{C}\right)$; (a) Eucalyptus $\left(600^{\circ} \mathrm{C}\right)$. 
Table 6. Effect of the temperature in the textural characterization of the bioreducers $\left(20^{\circ} \mathrm{C} \cdot \mathrm{min}^{-1}\right)$.

\begin{tabular}{ccccc}
\hline & Temperature $\left({ }^{\circ} \mathbf{C}\right)$ & Real Density $\left(\mathbf{g} \cdot \mathbf{c m}^{-3}\right)$ & $\begin{array}{c}\text { Micropore } \\
\text { Volume }\left(\mathbf{c m}^{\mathbf{3}} \cdot \mathbf{g}^{-1}\right)\end{array}$ & $\begin{array}{c}\text { Micropore Equivalent } \\
\text { Surface Area }\left(\mathbf{m}^{\mathbf{2}} \cdot \mathbf{g}^{-1}\right)\end{array}$ \\
\hline \multirow{2}{*}{ Olives } & 600 & 1.669 & 0.15 & 360 \\
& 750 & 1.926 & 0.16 & 375 \\
\hline \multirow{2}{*}{ Eucalyptus } & 600 & 1.622 & 0.19 & 444 \\
& 750 & 1.849 & 0.20 & 476 \\
\hline
\end{tabular}

The $\mathrm{CO}_{2}$ adsorption isotherms presented in Figure 1 show the $\mathrm{CO}_{2}$ volume adsorbed $\left(\mathrm{cm}^{3} \cdot \mathrm{g}^{-1}\right)$ against the relative pressure $\left(P / P_{0}\right)$. The $\mathrm{CO}_{2}$ adsorption isotherms are clearly of Type I that are typical of microporous materials. Although there is some controversy, it is frequently considered that the micropores volume determined by $\mathrm{CO}_{2}$ adsorption corresponds to narrow micropores $(<0.7 \mathrm{~nm})$.

The pore size distributions of the bioreducers samples calculated by the NL-DFT method are presented in Figure 2, which show that the bioreducers do not have micropores greater than $0.7 \mathrm{~nm}$, therefore, the micropores volume determined corresponds to the total pores volume.

Concerning the effect of the pyrolysis temperature, Table 6 shows that the real density clearly increases as the temperature is raised from $600{ }^{\circ} \mathrm{C}$ to $750{ }^{\circ} \mathrm{C}$, while the micropore volume and surface area also increases but very slightly.

The increase of micropore surface area with temperature is contrary to what has been observed by Burhenne, et al. [29] who reported a decrease in char surface area when the pyrolysis temperature was raised from $500{ }^{\circ} \mathrm{C}$ to $800{ }^{\circ} \mathrm{C}$. This discrepancy may be due to differences in the surface area determination methods: $\mathrm{N}_{2}$ (used by Burhenne) versus $\mathrm{CO}_{2}$ adsorption (used in this study). Burhenne's reasoning is that at higher temperature an occlusion of most micropores occurs; however it is plausible that what happens is that at higher pyrolysis temperature, narrower micropores are produced, and these, as will be explained next, are difficult to be measured with liquid $\mathrm{N}_{2}$.

Agirre, et al. [30] also found that the surface area increases when the pyrolysis temperature is raised. The reason for the increase of surface area with temperature may be that at higher temperatures greater amount of volatiles are driven out of the solid, giving rise to more micropores.

Concerning the effect of heating rate Figures 3 and 4 and Table 7 show the results obtained on the textural characterization of the solids obtained with olives and eucalyptus samples in pyrolysis at $750{ }^{\circ} \mathrm{C}$ with different heating rates.

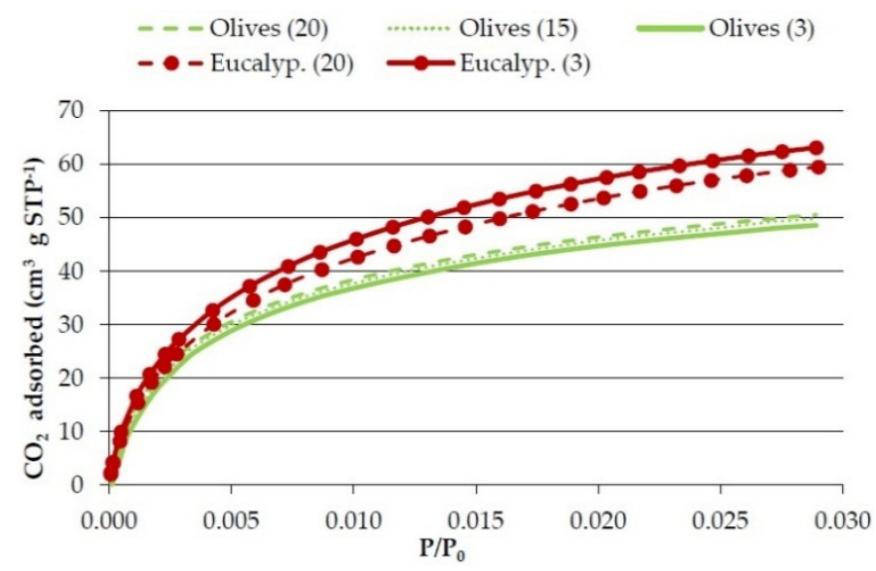

Figure 3. Effect of heating rate on $\mathrm{CO}_{2}$ adsorption isotherms of the bioreducers obtained at $750{ }^{\circ} \mathrm{C}$ from the olives and eucalyptus samples. 


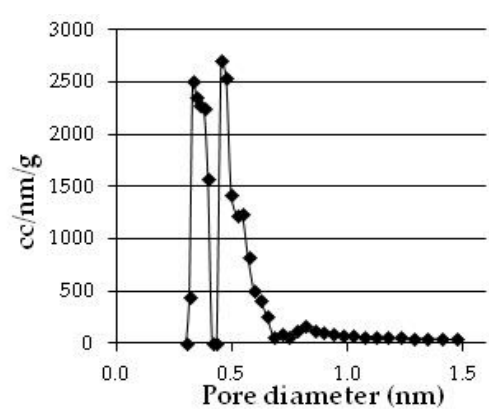

(a)

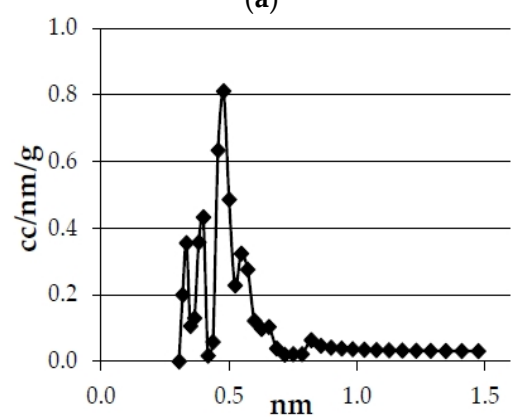

(c)

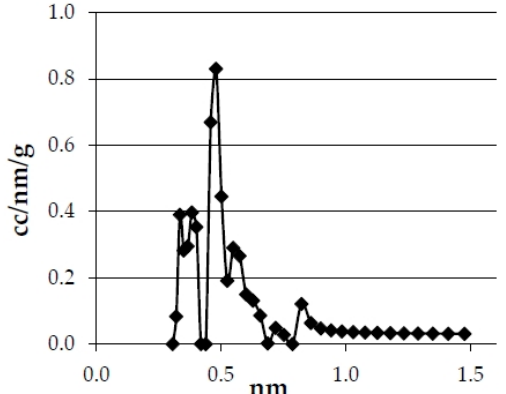

(b)

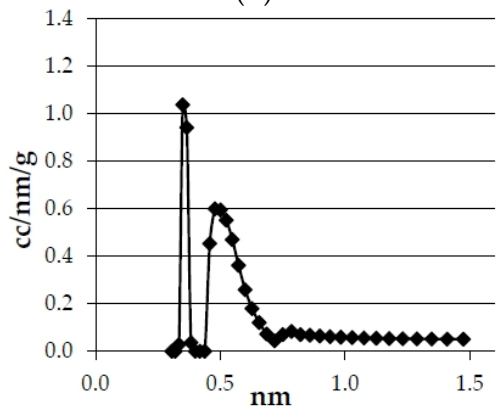

(d)

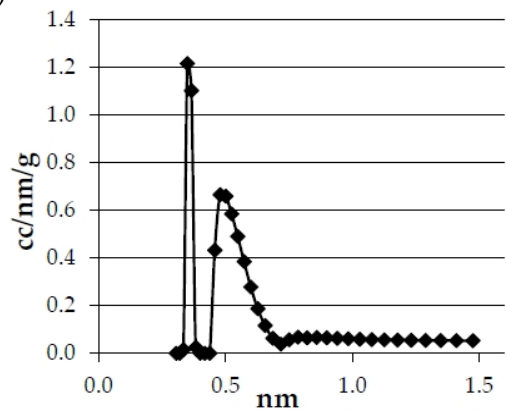

(e)

Figure 4. Effect of heating rate in pore size distribution of the bioreducers obtained at $750{ }^{\circ} \mathrm{C}$ from the olives and eucalyptus samples. (a) Olives $20^{\circ} \mathrm{C} \cdot \mathrm{min}^{-1}$; (b) Olives $15^{\circ} \mathrm{C} \cdot \mathrm{min}^{-1}$; (c) Olives $3{ }^{\circ} \mathrm{C} \cdot \mathrm{min}^{-1}$; (d) Eucalyptus $20^{\circ} \mathrm{C} \cdot \mathrm{min}^{-1}$; (e) Eucalyptus $3^{\circ} \mathrm{C} \cdot \mathrm{min}^{-1}$.

Table 7. Effect of heating rate in the textural characterization of the bioreducers $\left(750^{\circ} \mathrm{C}\right)$.

\begin{tabular}{ccccc}
\hline \multirow{2}{*}{ Olives } & $\begin{array}{c}\text { Heating Rate } \\
\left({ }^{\circ} \mathbf{C} \cdot \mathbf{~ m i n}^{-1} \mathbf{)}\right.\end{array}$ & $\begin{array}{c}\text { Real Density } \\
\left(\mathbf{g} \cdot \mathbf{~ c m}^{-3}\right)\end{array}$ & $\begin{array}{c}\text { Micropore } \\
\text { Volume }\left(\mathbf{c m}^{\mathbf{3}} \cdot \mathbf{g}^{-1}\right)\end{array}$ & $\begin{array}{c}\text { Micropore Equivalent } \\
\text { Surface Area }\left(\mathbf{m}^{\mathbf{2}} \cdot \mathbf{g}^{-1} \mathbf{)}\right.\end{array}$ \\
\hline \multirow{2}{*}{ Eucalyptus } & 20 & 1.926 & 0.16 & 375 \\
& 15 & 1.867 & 0.15 & 362 \\
& 3 & 1.871 & 0.15 & 363 \\
\hline
\end{tabular}

There is no clear influence of heating rate on the textural properties. Table 7 shows that in the case of olives the real density, micropore volume, and surface area somewhat decrease with the decrease in the heating rate, but in the case of the eucalyptus sample the density also decreases but the micropore volume and surface area somewhat increase. Figures 3 and 4 also show a different effect of heating rate in olive solids and in eucalyptus solids. It has been reported that the longer the char residence time, the greater its surface area [31,32]. This was not the case in this study, which may be due to the fact that $20^{\circ} \mathrm{C} \cdot \mathrm{min}^{-1}$ is a low enough heating rate under which no further increase in surface area is produced. 
If the surface areas of the bioreducers are compared to those presented in the literature, it can be seen that there are great differences. Very low charcoal surface areas have been reported by several authors: Huo, et al. [33] reported $\mathrm{N}_{2} \mathrm{BET}$ area $<9 \mathrm{~m}^{2} \cdot \mathrm{g}^{-1}$ for chars obtained at $900{ }^{\circ} \mathrm{C}$ from saw dust and straw, Burhenne, et al. [29] reported $\mathrm{N}_{2}$ BET area $\approx 1 \mathrm{~m}^{2} \cdot \mathrm{g}^{-1}$ for spruce wood chars obtained at $800{ }^{\circ} \mathrm{C}$, Senneca [34] also reported $\mathrm{N}_{2}$ BET areas $<1 \mathrm{~m}^{2} \cdot \mathrm{g}^{-1}$ for char samples obtained from pine wood at $850^{\circ} \mathrm{C}$.

On the contrary, other authors report surface areas in the range of those obtained in this study. Rösler, et al. [35] obtained surface areas (measured by $\mathrm{CO}_{2}$ adsorption) between 325 and $425 \mathrm{~m}^{2} \cdot \mathrm{g}^{-1}$ for biochars obtained at $750{ }^{\circ} \mathrm{C}$, Burhenne, et al. [29] obtained BET areas of $200-400 \mathrm{~m}^{2} \cdot \mathrm{g}^{-1}$ for chars produced at $500{ }^{\circ} \mathrm{C}$, and Carrier, et al. [36] reported a $\mathrm{N}_{2}$ BET area of $259 \mathrm{~m}^{2} \cdot \mathrm{g}^{-1}$ for char obtained from sugarcane bagasse at $460{ }^{\circ} \mathrm{C}$ and $349-452 \mathrm{~m}^{2} \cdot \mathrm{g}^{-1}$ for that same char but after heating it to $800{ }^{\circ} \mathrm{C}$ and $900{ }^{\circ} \mathrm{C}$ in a $\mathrm{N}_{2}$ atmosphere, as well as $441-570 \mathrm{~m}^{2} \cdot \mathrm{g}^{-1}$ after activating the char with steam at $700-900{ }^{\circ} \mathrm{C}$.

The reason for these differences in the surface areas is, most probably, the determination method used. As has been mentioned before, it is difficult to obtain reliable results with $\mathrm{N}_{2}$ adsorption methods with carbonaceous materials, since it is carried at $-196^{\circ} \mathrm{C}$ and at such low temperature, $\mathrm{N}_{2}$ has diffusion problems in the narrow micropores and therefore, it may take a long time to reach thermodynamic adsorption equilibrium, it may take (if reached) even weeks. Another reason for erroneous BET area measurements with liquid $\mathrm{N}_{2}$ that has been reported in the literature [37], is that there can be pore shrinkage, so that the measured surface areas are apparent, and not real. In this study, in the first place, it was tried to determine the surface areas by liquid $\mathrm{N}_{2}$ adsorption, but for most of the bioreducers samples the equilibrium was not reached, even after a week, and in those samples that reached equilibrium, the BET area obtained was very low $\left(7-15 \mathrm{~m}^{2} \cdot \mathrm{g}^{-1}\right)$.

The bioreducers obtained in this study have surface areas comparable to those reported by Carrier, et al. [36]. In particular, the eucalyptus derived bioreducers present surface areas (476-501 $\mathrm{m}^{2} \cdot \mathrm{g}^{-1}$ ) equivalent to those reported by Carrier, et al. [36] for sugarcane derived chars activated with steam at $700-900{ }^{\circ} \mathrm{C}$ for 1 hour $\left(441-570 \mathrm{~m}^{2} \cdot \mathrm{g}^{-1}\right)$. Therefore, the eucalyptus bioreducers could be used as a sorbent material without needing to be activated. However, it has to be mentioned that the surface area of the eucalyptus bioreducers, the same as that of Carrier, et al. [36] activated chars, are well below commercial activated carbon values (BET area $\approx 1000 \mathrm{~m}^{2} \cdot \mathrm{g}^{-1}$ ).

A comparison between the textural properties of the three commercial reducing agents and of the pyrolysis solids obtained from olives and eucalyptus samples at $750{ }^{\circ} \mathrm{C}$ and $3{ }^{\circ} \mathrm{C} \cdot \mathrm{min}^{-1}$ are presented in Table 8.

Table 8. Textural characterization of commercial reducers and bioreducers $\left(750^{\circ} \mathrm{C}\right.$ and $\left.3{ }^{\circ} \mathrm{C} \cdot \min ^{-1}\right)$.

\begin{tabular}{cccc}
\hline & Real Density $\left(\mathbf{g} \cdot \mathbf{~ c m}^{-3}\right)$ & $\begin{array}{c}\text { Micropore Volume } \\
\left(\mathbf{c m}^{\mathbf{3}} \cdot \mathbf{g}^{-1} \mathbf{)}\right.\end{array}$ & $\begin{array}{c}\text { Micropore Equivalent } \\
\text { Surface Area }\left(\mathbf{m}^{\mathbf{2}} \cdot \mathbf{g}^{-1} \mathbf{)}\right.\end{array}$ \\
\hline Olives & 1.871 & 0.15 & 363 \\
Eucalyptus & 1.830 & 0.21 & 501 \\
Metallurgical coke & 1.916 & 0.01 & 24 \\
Petroleum coke & 1.389 & 0.07 & 156 \\
Anthracite & 1.793 & 0.05 & 122 \\
\hline
\end{tabular}

Concerning real density, Table 8 shows that the bioreducers are comparable to metallurgical coke and anthracite, while petroleum coke has a significantly lower real density. This may be attributed to the lower ash content and the higher micropore volume of petroleum coke.

With respect to surface area, it can be seen that the bioreducers surface areas are much greater than those of the commercial reducers. Therefore, a higher reactivity of the bioreducers compared to the commercial reducers might be expected (this will be discussed in the following section). 
Figure 5 shows the $\mathrm{CO}_{2}$ adsorption isotherms of the three commercial reducing agents and of the pyrolysis solids obtained from olives and eucalyptus samples at $750{ }^{\circ} \mathrm{C}$ and $3{ }^{\circ} \mathrm{C} \cdot \mathrm{min}^{-1}$. It has to be mentioned that although it is not clearly visible (due to the scale) the commercial reducers isotherms are also Type I, which is typical of microporous materials. However, as might have been expected, according to the surface area data, the commercial reducers' curves are much lower than those of the bioreducers.

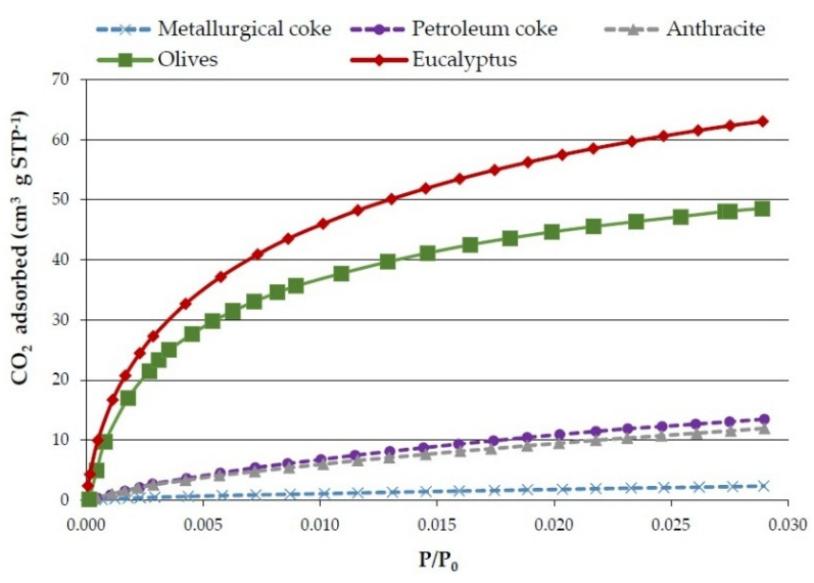

Figure 5. $\mathrm{CO}_{2}$ adsorption isotherms of commercial reducers and olives and eucalyptus bioreducers (obtained at $750{ }^{\circ} \mathrm{C}$ and $3{ }^{\circ} \mathrm{C} \cdot \mathrm{min}^{-1}$ ).

The pore size distributions of the bioreducers and the commercial reducing agents calculated by the NL-DFT method are presented in Figure 6. It can be seen that there are important differences between the curves that correspond to the commercial reducers and the pore size distribution of the bioreducers. First of all, the amount of pore of each size is much smaller in the commercial reducers than in the bioreducers. It has to be born in mind that the $y$-axis scale is about 10 times lower in the commercial reducers' graphs than in the bioreducers' graphs.

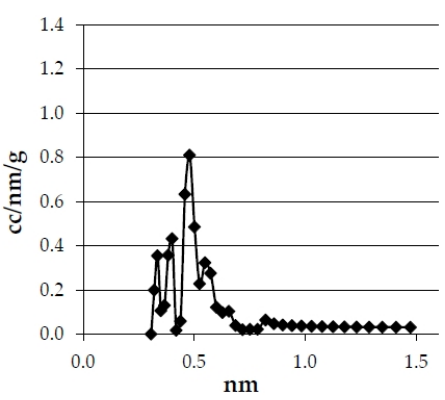

(a)

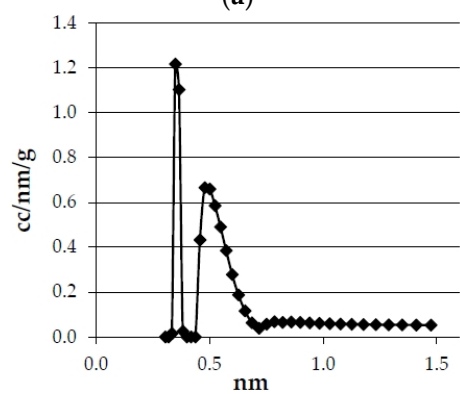

(c)

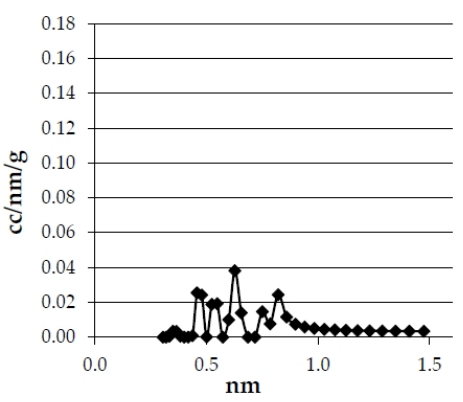

(b)

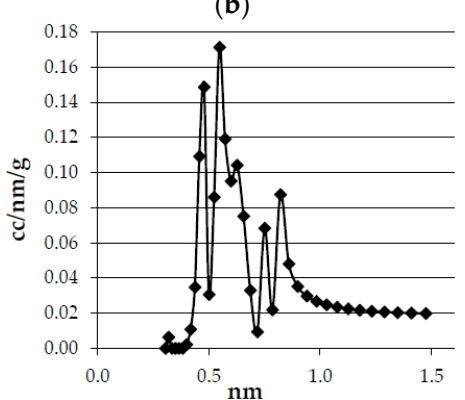

(d)

Figure 6. Cont. 


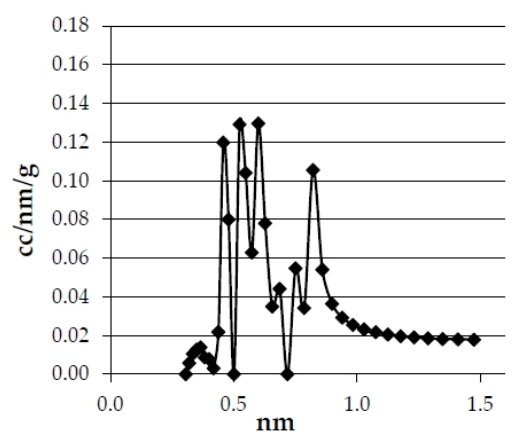

(e)

Figure 6. Pore size distribution of commercial reducers and olives and eucalyptus bioreducers (obtained at $750{ }^{\circ} \mathrm{C}$ and $3{ }^{\circ} \mathrm{C} \cdot \mathrm{min}^{-1}$ ). (a) Olives; (b) Metallurgical coke; (c) Eucalyptus; (d) Petroleum coke; (e) Anthracite.

To summarize, the main conclusion concerning the comparison of the bioreducers with the commercial reducing agents is that, although in terms of composition (proximate and ultimate analyses) both types of reducing agents are quite similar, or even better, the bioreducers, in terms of surface area and porosity, are very different, and this brings about, as will be seen in the following section, different reactivity behaviors.

\subsection{Reactivity}

The reactivity experiments carried out were classified in the following three groups:

- Reactivity tests with the three commercial reducers (metallurgical coke, petroleum coke, and anthracite) using $50 \mathrm{~g}$ of sample and $1375 \mathrm{~mL} \cdot \mathrm{min}^{-1}$ of $\mathrm{CO}_{2}$ flow.

- Reactivity tests with metallurgical coke using different amounts of sample and two $\mathrm{CO}_{2}$ flow ratios $\left(1375 \mathrm{~mL} \cdot \mathrm{min}^{-1}\right.$ and $\left.750 \mathrm{~mL} \cdot \mathrm{min}^{-1}\right)$.

- Reactivity tests with the two bioreducers (olives and eucalyptus) using $30 \mathrm{~g}$ of sample and $750 \mathrm{~mL} \cdot \mathrm{min}^{-1}$ of $\mathrm{CO}_{2}$ flow.

The reasons for performing these three sets of experiments as well as the results obtained are explained in the following section.

\subsubsection{Reactivity Tests with the Commercial Reducers}

The objective of this first set of reactivity tests was to determine the reactivity behavior of the reducing agents used and provided by Befesa Zinc Aser S.A. (metallurgical coke, petroleum coke, and anthracite). As has been mentioned in Section 2.2.2 the reactivity tests were performed based on the ASTM D 5341-99 standard but with a smaller amount of sample. In this first set of tests, $50 \mathrm{~g}$ of sample and $1375 \mathrm{~mL} \cdot \mathrm{min}^{-1} \mathrm{CO}_{2}$ flow were used, which are proportional to the specifications of the ASTM standard.

The results obtained of both, CRI and R factor, are presented in Table 9. It can be seen that the metallurgical coke and anthracite have similar reactivities according to both, their CRI and R factor, while both parameters are significantly lower for the petroleum coke. Agirre, et al. [30] have reported CRI and $R$ values for a typical commercial petroleum coke (13.7\% and $16.5 \%$, respectively) which are comparable but somewhat lower than those obtained in this study ( $16.5 \%$ and $20.0 \%$, respectively). Other authors have also observed that petroleum cokes have lower reactivities than metallurgical cokes [38]. It has been reported that this may be because petroleum coke has somewhat more crystalline structures which are less reactive [39]. 
Table 9. Reactivity results of commercial reducing agents $\left(50 \mathrm{~g}\right.$ and $\left.1375 \mathrm{~mL} \cdot \mathrm{min}^{-1} \mathrm{CO}_{2}\right)$.

\begin{tabular}{cccc}
\hline & Metallurgical Coke & Petroleum Coke & Anthracite \\
\hline CRI (\%) & $30.9 \pm 0.1$ & $16.5 \pm 0.2$ & $31.6 \pm 0.7$ \\
$R$ factor $(\%)$ & $47.4 \pm 1.8$ & $20.0 \pm 0.1$ & $47.4 \pm 0.6$ \\
\hline
\end{tabular}

After this first set of reactivity tests, it was attempted to determine the reactivity of the pyrolysis solids. However, due to the lower apparent density of these solids $\left(0.45 \mathrm{~g} \mathrm{~cm}^{-3}\right.$ for olives and $0.42 \mathrm{~g} \cdot \mathrm{cm}^{-3}$ for eucalyptus, compared to 1.11 for metallurgical coke, 0.72 for petroleum coke and 1.31 for anthracite), it was not possible to introduce $50 \mathrm{~g}$ of sample in the tubular reactor. Therefore, it was decided to carry out some experiments to investigate if the amount of sample used could have an influence on the results obtained on the reactivity tests. The results are presented in the following section.

3.3.2. Reactivity Tests of the Metallurgical Coke with Different Amounts of Sample and Different $\mathrm{CO}_{2}$ Flows

The CRI and $R$ factor obtained with the metallurgical coke using different amounts of sample and different $\mathrm{CO}^{2}$ flows are presented in Table 10.

Table 10. Reactivity results of metallurgical coke.

\begin{tabular}{cccccc}
\hline & \multicolumn{3}{c}{$\mathbf{1 3 7 5} \mathbf{~} \mathbf{L} \cdot \mathbf{~ m i n}^{-1}$} & & $\mathbf{7 5 0} \mathbf{~} \mathbf{L} \cdot \mathbf{~ m i n}^{-1}$ \\
\cline { 2 - 4 } & $\mathbf{5 0} \mathbf{g}$ & $\mathbf{3 0} \mathbf{~ g}$ & $\mathbf{1 5} \mathbf{~}$ & & $\mathbf{3 0} \mathbf{~}$ \\
\hline CRI (\%) & $30.9 \pm 0.1$ & $43.5 \pm 1.3$ & $41.0 \pm 2.0$ & & $34.5 \pm 0.5$ \\
$R$ factor $(\%)$ & $47.4 \pm 1.8$ & $27.0 \pm 0.4$ & $9.8 \pm 0.1$ & & $45.9 \pm 1.2$ \\
\hline
\end{tabular}

The reactivity results obtained with $1375 \mathrm{~mL} \cdot \mathrm{min}^{-1} \mathrm{CO}_{2}$ flow and with different amounts of sample show that the CRI index significantly increases when the amount of sample is reduced from $50 \mathrm{~g}$ to $30 \mathrm{~g}$, but no further increase is observed from $30 \mathrm{~g}$ to $15 \mathrm{~g}$. The explanation of this fact may be the following: the greater the amount of sample, the larger is the height occupied by it inside the tubular reactor; the $\mathrm{CO}_{2}$ stream is fed into the reactor through the bottom, therefore it starts reacting with the coke, and as it goes up through the char bed it is impoverished in $\mathrm{CO}_{2}$, leading to a lower reaction rate at the upper part of the reactor. This effect is not observed from the $15 \mathrm{~g}$ to the $30 \mathrm{~g}$ tests probably because with smaller column heights there is $\mathrm{CO}_{2}$ enough all through the column both with the 15 and the $30 \mathrm{~g}$ samples and therefore, the negative effect of increasing the amount of sample is not observed in this range.

Regarding the $R$ factor, it clearly decreases when the amount of sample is reduced in the whole mass sample range. This was obviously the expected trend, since as less sample is used, less total CO is produced, and consequently, for the same $\mathrm{CO}_{2}$ flow, the $\mathrm{CO} / \mathrm{CO}_{2}$ ratio is lower and therefore, the $\mathrm{R}$ factor as well.

Comparing the results obtained with $30 \mathrm{~g}$ of sample at the two different $\mathrm{CO}_{2}$ flows, it was observed that the CRI decreases while the $R$ factor increases as the $\mathrm{CO}_{2}$ flow decreases. This was to be expected since, if there is less $\mathrm{CO}_{2}$ available for the same amount of sample, on the one hand, less coke reacts and therefore, the weight loss is smaller, and consequently the CRI decreases. On the other hand, since the $\mathrm{CO}_{2}$ concentration is much lower, even though less $\mathrm{CO}$ has been produced, the $\mathrm{CO} / \mathrm{CO}_{2}$ ratio increases, and consequently, the $\mathrm{R}$ factor increases.

If the results obtained with $30 \mathrm{~g}$ and $750 \mathrm{~mL} \cdot \mathrm{min}^{-1}$ are compared with those obtained with $50 \mathrm{~g}$ and $1375 \mathrm{~mL} \cdot \mathrm{min}^{-1}$, it can be seen that they are quite similar, which is attributed to the fact that the amount of sample $/ \mathrm{CO}_{2}$ flow ratio used in these two tests is quite similar $(\approx 26)$. 
Therefore, it has been demonstrated that in the reactivity tests the amount of sample used, plays a very important role, but that if the amount of sample $/ \mathrm{CO}_{2}$ flow ratio is kept constant, the influence of the amount of sample can be neglected.

Therefore, the reactivity tests of the bioreducers, which are presented in the following section, were carried out with $30 \mathrm{~g}$ of sample and $750 \mathrm{~mL} \cdot \mathrm{min}^{-1} \mathrm{CO}_{2}$ flow, so that they could be compared with the reactivity tests of the commercial reducers carried out with $50 \mathrm{~g}$ and $1375 \mathrm{~mL} \cdot \mathrm{min}^{-1} \mathrm{CO}_{2}$.

\subsubsection{Reactivity Tests with the Bioreducers}

The results of the reactivity tests of the pyrolysis solids (olives and eucalyptus) carried out using $30 \mathrm{~g}$ and $750 \mathrm{~mL} \cdot \mathrm{min}^{-1} \mathrm{CO}_{2}$ are included in Table 11. It has to be mentioned that the error of these measurements could not be determined in all cases due to the shortage of sample which made it impossible to repeat some of the tests. In those cases in which the errors were determined, the CRI error was in the range $1-3$ and the $R$ factor error in the range $2-4$.

Table 11. Reactivity results of pyrolysis bioreducers $\left(750^{\circ} \mathrm{C}\right)\left(30 \mathrm{~g}\right.$ and $\left.750 \mathrm{~mL} \cdot \mathrm{min}^{-1} \mathrm{CO}_{2}\right)$.

\begin{tabular}{cccccc}
\hline & \multicolumn{3}{c}{ Olives } & & Eucalyptus \\
\cline { 2 - 3 } & $\mathbf{2 0}{ }^{\circ} \mathbf{C} \cdot \mathbf{~ m i n}^{-1}$ & $\mathbf{1 5}^{\circ} \mathbf{C} \cdot \mathbf{m i n}^{-1}$ & $\mathbf{3}^{\circ} \mathbf{C} \cdot \mathbf{m i n}^{-1}$ & & $\mathbf{3}^{\circ} \mathbf{C} \cdot \mathbf{m i n}^{-1}$ \\
\hline CRI $(\%)$ & 87.8 & 86.8 & 86.1 & \\
$R$ factor $(\%)$ & 81.3 & 82.4 & 74.4 & \\
\hline
\end{tabular}

It can be seen that the reactivity of the bioreducers is very high. In the case of the olives sample, the CRI values are around $87 \%$ therefore only $13 \%$ of the initial mass has not reacted in the reactivity test. Taking into account that the ash contents of the olive derived bioreducers is close to $10 \%$ (Table 5) it can be concluded that the sample has almost completely reacted with $\mathrm{CO}_{2}$. The same happens in the case of the eucalyptus derived bioreducer: the CRI value is as high as $94 \%$ when it has an ash content of $5.4 \%$. Therefore, the values in Table 11 can be considered to be the maximum achievable reactivities. Burhenne, et al. [29] also obtained almost $100 \%$ reactivity of spruce wood derived char in tests carried out both in TGA at $800{ }^{\circ} \mathrm{C}$ for $3-5 \mathrm{~h}$ and in a fixed bed reactor at $800^{\circ} \mathrm{C}$ for $30 \mathrm{~min}$. For this reason, a discussion of the influence of the heating rate or type of sample on the reactivity of the bioreducers obtained in this study does not deserve attention.

Comparing Tables 9 and 11 it can be seen that the reactivity of bioreducers is far higher than that of the commercial reducers. This may be attributed to the fact that the surface areas of the commercial reducers are much lower $\left(24-156 \mathrm{~m}^{2} \cdot \mathrm{g}^{-1}\right)$ than those of the bioreducers derived from olives and eucalyptus samples $\left(363-501 \mathrm{~m}^{2} \cdot \mathrm{g}^{-1}\right)$. Huo, et al. [33] also obtained much higher reactivities of bioreducers than of petroleum coke or anthracite, and they also reported that there was a relationship between reactivity and surface area.

On the contrary, bioreducers obtained by pyrolysis of fruit tree cuttings at $900{ }^{\circ} \mathrm{C}$ by Agirre, et al. [30], have CRI values in the range of $20 \%-50 \%$ and $R$ factor $35 \%-70 \%$, both values much lower than those obtained in this study, and comparable to those of commercial reducing agents. There are several reasons to explain these differences: (1) on the one hand, the equipment used for reactivity measurements by Agirre, et al., is very different from the one used in this study; it is a horizontal tubular furnace and the sample is placed in a crucible inside the reactor, therefore the $\mathrm{CO}_{2}$ stream is only in contact with the upper surface of the sample, while in this study a vertical reactor is used, and therefore the $\mathrm{CO}_{2}$ stream goes through the whole bioreducer bed; (2) the reaction time once reached at the reaction temperature $\left(1000^{\circ} \mathrm{C}\right)$ used by Agirre, et al., was only $15 \mathrm{~min}$ instead of $2 \mathrm{~h}$ which is the time specified in the ASTM D 5341-99 and the one used in the reactivity tests of this study; (3) the particle size used by Agirre, et al., $(4-5 \mathrm{~cm})$ was larger than that used in this study $(1 \mathrm{~cm}) ;(4)$ the type of original biomass from which bioreducers were derived was different (fruit tree 
cuttings $v s$. olive tree cuttings and eucalyptus); this fact, although less influential than the previous ones, may also be of importance.

In view of the characteristics of the olive and eucalyptus derived bioreducers and in order to analyze their suitability for metallurgical processes, it is worth mentioning that there are three roles that coke plays in metallurgical processes: (1) it has to provide heat or energy; (2) it has to provide a reducing atmosphere by means of the reaction: $\mathrm{C}+\mathrm{CO}_{2} \leftrightarrow 2 \mathrm{CO}$; (3) it has to act as a support medium for the burden if the process is carried out in a blast furnace.

The first two requirements are well fulfilled by the bioreducers obtained in this study; they have rather high heating values $\left(\approx 30 \mathrm{MJ} \cdot \mathrm{kg}^{-1}\right)$ and they are fully reactive. However, bioreducers cannot fulfill the third requirement, and therefore, due to their missing strength and high reactivity, cannot be used in blast furnaces as support medium, but they can be used tuyére-injected in the lower part of the blast furnaces to substitute typically used fossil fuels (pulverized carbon, oils, natural gas). On the other hand, bioreducers can also be used in the non-ferrous metal industry since no mechanical strength is required, because rotary kilns, where the burden is mixed and rotates with the coke, are frequently used.

Nevertheless, the final decision to determine the suitability of bioreducers for the non-ferrous metallurgical industry depends on the specific characteristics of the process itself. Metal reduction experiments should be carried out with the bioreducers in order to determine if the high reactivities could be a handicap for the process, but such kind of experiments were beyond the scope of this paper. However, it has been reported in the literature, experiments on the reduction of electric arc furnace dusts carried out with charcoal which show that with bioreducers higher zinc volatilization and iron oxide reduction can be achieved in comparison to those obtained with the fossil cokes normally used in industry [15].

\section{Conclusions}

As far as proximate and ultimate analyses are concerned, olives and eucalyptus derived reducing agents (bioreducers) are of better quality than typical commercial reducing agents used in non-ferrous processes (metallurgical coke, petroleum coke, anthracite), since the former have lower ash and sulfur contents.

The surface area and porosity of the bioreducers obtained in this study (363-501 $\mathrm{m}^{2} \cdot \mathrm{g}^{-1}$ and $0.15-0.21 \mathrm{~cm}^{3} \cdot \mathrm{g}^{-1}$, respectively) are much higher than those of typical commercial reducing agents used in metallurgical processes in rotary kilns $\left(24-156 \mathrm{~m}^{2} \cdot \mathrm{g}^{-1}\right.$ and $0.01-0.07 \mathrm{~cm}^{3} \cdot \mathrm{g}^{-1}$, respectively).

The bioreducers reactivity measurements with $\mathrm{CO}_{2}$ are very much conditioned by the experimental procedure used. If the ASTM D 5314-99 standard procedure cannot be strictly followed due to sample shortage, a mass sample $/ \mathrm{CO}_{2}$ flow ratio equivalent to that of the ASTM standard should be used.

The bioreducers obtained in this study have no mechanical strength and present extremely high reactivity with $\mathrm{CO}_{2}$ (close to $100 \%$ ). Therefore, they cannot be used as top burden in blast furnaces, but they can be used as fuel and reducing agent either tuyére-injected at the lower part of the blast furnace or in non-ferrous metallurgical processes where no mechanical strength is needed, such as in rotary kilns.

Acknowledgments: The authors thank the University of the Basque Country (US 11/21), the Basque Country Government (GIC 10/31), MEC the Spanish Ministry of Science and Innovation (ENE 2011-23950) and BEFESA Steel R\&D Company for financial assistance for this work.

Author Contributions: Isabel De Marco and Alexander López-Urionabarrenechea conceived and designed the experiments; Aitziber Adrados, Jon Solar and Naia Gastelu performed the experiments; Aitziber Adrados, Isabel De Marco and Blanca M. Caballero analyzed the data; Alexander López-Urionabarrenechea and Jon Solar contributed reagents/materials/analysis tools; Aitziber Adrados and Isabel De Marco wrote the paper.

Conflicts of Interest: The authors declare no conflict of interest. 


\section{References}

1. Suopajärvi, H.; Pongrácz, E.; Fabritius, T. The potential of using biomass-based reducing agents in the blast furnace: A review of thermochemical conversion technologies and assessments related to sustainability. Renew. Sustain. Energy Rev. 2013, 25, 511-528. [CrossRef]

2. Montiano, M.G.; Díaz-Faes, E.; Barriocanal, C.; Alvarez, R. Influence of biomass on metallurgical coke quality. Fuel 2014, 116, 175-182. [CrossRef]

3. Díez, M.A.; Borrego, A.G. Evaluation of $\mathrm{CO}_{2}$-reactivity patterns in cokes from coal and woody biomass blends. Fuel 2013, 113, 59-68. [CrossRef]

4. EPA Overview of Greenhouse Gases. Available online: http://www.epa.gov/climatechange/ghgemissions/ gases/co2.html (accessed on 21 December 2015).

5. World Resources Institute Understanding the IPCC Reports. Available online: http://www.wri.org/ ipcc-infographics (accessed on 21 December 2015).

6. UNFCCC Background on the UNFCCC: The International Response to Climate Change. Available online: http://unfccc.int/essential_background/items/6031.php (accessed on 21 December 2015).

7. Avila, C.; Pang, C.H.; Wu, T.; Lester, E. Morphology and reactivity characteristics of char biomass particles. Bioresour. Technol. 2011, 102, 5237-5243. [CrossRef] [PubMed]

8. Demirbaş, A. Carbonization ranking of selected biomass for charcoal, liquid and gaseous products. Energy Convers. Manag. 2001, 42, 1229-1238. [CrossRef]

9. Elyounssi, K.; Collard, F.-X.; Mateke, J.N.; Blin, J. Improvement of charcoal yield by two-step pyrolysis on eucalyptus wood: A thermogravimetric study. Fuel 2012, 96, 161-167. [CrossRef]

10. Park, S.-W.; Jang, C.-H.; Baek, K.-R.; Yang, J.-K. Torrefaction and low-temperature carbonization of woody biomass: Evaluation of fuel characteristics of the products. Energy 2012, 45, 676-685. [CrossRef]

11. Xiao, L.-P.; Shi, Z.-J.; Xu, F.; Sun, R.-C. Hydrothermal carbonization of lignocellulosic biomass. Bioresour. Technol. 2012, 118, 619-623. [CrossRef] [PubMed]

12. Xu, R.; Ferrante, L.; Hall, K.; Briens, C.; Berruti, F. Thermal self-sustainability of biochar production by pyrolysis. J. Anal. Appl. Pyrolysis 2011, 91, 55-66. [CrossRef]

13. Díez, M.A.; Alvarez, R.; Barriocanal, C. Coal for metallurgical coke production: Predictions of coke quality and future requirements for cokemaking. Int. J. Coal Geol. 2002, 50, 389-412. [CrossRef]

14. Griessacher, T.; Antrekowitsch, J. Alternative reducing agents in the recycling of heavy metal-containing residues. Proc. EMC 2011, 4, 1349-1362.

15. Griessacher, T.; Antrekowitsch, J.; Steinlechner, S. Charcoal from agricultural residues as alternative reducing agent in metal recycling. Biomass Bioenergy 2012, 39, 139-146. [CrossRef]

16. Demirbas, A. Effects of temperature and particle size on bio-char yield from pyrolysis of agricultural residues. J. Anal. Appl. Pyrolysis 2004, 72, 243-248. [CrossRef]

17. Angin, D. Effect of pyrolysis temperature and heating rate on biochar obtained from pyrolysis of safflower seed press cake. Bioresour. Technol. 2013, 128, 593-597. [CrossRef] [PubMed]

18. Standard Test Method for Measuring Coke Reactivity Index (CRI) and Coke Strength After Reaction (CSR); ASTM D 5341-99; ASTM International: West Conshohocken, PA, USA, 2004; Volume 99.

19. Lundgren, M.; Ökvist, L.S.; Björkman, B. Coke reactivity under blast furnace conditions and in the CSR/CRI Test. Steel Res. Int. 2009, 80, 396-401. [CrossRef]

20. ESYRCE. Encuesta sobre superficies y rendimientos de cultivos. 2015. Available online: http://agricultura.gencat.cat/ web/.content/de_departament/de02_estadistiques_observatoris/21_aigua/fitxers_estatics/estudioregadios2008.pdf (accessed on 21 December 2015).

21. García-Maraver, A.; Zamorano, M.; Ramos-Ridao, A.; Díaz, L.F. Analysis of olive grove residual biomass potential for electric and thermal energy generation in Andalusia (Spain). Renew. Sustain. Energy Rev. 2012, 16, 745-751. [CrossRef]

22. Räisänen, T.; Athanassiadis, D. Basic chemical composition of the biomass components of pine, spruce and birch. Available online: http://www.biofuelregion.se/UserFiles/file/Forest Refine/1_2_IS_2013-01-31 _Basic_chemical_composition.pdf (accessed on 21 December 2015).

23. Adrados, A.; Lopez-Urionabarrenechea, A.; Solar, J.; Requies, J.; de Marco, I.; Cambra, J.F. Upgrading of pyrolysis vapours from biomass carbonization. J. Anal. Appl. Pyrolysis 2013, 103, 293-299. [CrossRef] 
24. Ibarrola, R.; Hammond, J.; Shackley, S. Pyrolysis biochar systems for recovering biodegradable materials: A life cycle carbon assessment. Waste Manag. 2012, 32, 859-868. [CrossRef] [PubMed]

25. Lehmann, J.; Joseph, S. Biochar for Environmental Management Science and Technology; Sterling, VA: London, UK, 2009.

26. Adrados, A. Optimization of the Pyrolysis Process for the Production of a Biomass Derived Reducing Agent and Hydrogen-Rich Gases; University of the Basque Country (UPV/EHU): Bilbao, Spain, 2014.

27. Imam, T.; Capareda, S. Characterization of bio-oil, syn-gas and bio-char from switchgrass pyrolysis at various temperatures. J. Anal. Appl. Pyrolysis 2012, 93, 170-177. [CrossRef]

28. U.S. Deparment of Energy Lower and Higher Heating Values of Hydrogen and Other Fuels. Available online: http:/ / www.centreflow.ca/2011/03/15/natural-gas-is-more-energetic/ (accessed on 21 December 2015).

29. Burhenne, L.; Damiani, M.; Aicher, T. Effect of feedstock water content and pyrolysis temperature on the structure and reactivity of spruce wood char produced in fixed bed pyrolysis. Fuel 2013, 107, 836-847. [CrossRef]

30. Agirre, I.; Griessacher, T.; Rösler, G.; Antrekowitsch, J. Production of charcoal as an alternative reducing agent from agricultural residues using a semi-continuous semi-pilot scale pyrolysis screw reactor. Fuel Process. Technol. 2013, 106, 114-121. [CrossRef]

31. Dutta, B.; Raghavan, G.S.V.; Ngadi, M. Surface characterization and classification of slow and fast pyrolyzed biochar using novel methods of pycnometry and hyperspectral imaging. J. Wood Chem. Technol. 2012, 32, 105-120. [CrossRef]

32. Hasan Khan Tushar, M.S.; Mahinpey, N.; Khan, A.; Ibrahim, H.; Kumar, P.; Idem, R. Production, characterization and reactivity studies of chars produced by the isothermal pyrolysis of flax straw. Biomass Bioenergy 2012, 37, 97-105. [CrossRef]

33. Huo, W.; Zhou, Z.; Chen, X.; Dai, Z.; Yu, G. Study on $\mathrm{CO}_{2}$ gasification reactivity and physical characteristics of biomass, petroleum coke and coal chars. Bioresour. Technol. 2014, 159, 143-149. [CrossRef] [PubMed]

34. Senneca, O. Kinetics of pyrolysis, combustion and gasification of three biomass fuels. Fuel Process. Technol. 2007, 88, 87-97. [CrossRef]

35. Rösler, G.; Griessacher, T.; Antrekowitsch, J. The influence of charcoal properties on its applicability in metallurgical operations. In Proceedings of the 4th International Symposium on Energy from Biomass and Waste, Venice, Italy, 12-15 November 2012.

36. Carrier, M.; Hardie, A.G.; Uras, Ü.; Görgens, J.; Knoetze, J.H. Production of char from vacuum pyrolysis of South-African sugar cane bagasse and its characterization as activated carbon and biochar. J. Anal. Appl. Pyrolysis 2012, 96, 24-32. [CrossRef]

37. Jones, J.C. Letter: The BET surface areas of carbonised biomass. Fuel Process. Technol. 2012, $106,784$. [CrossRef]

38. Menéndez, J.A.; Pis, J.J.; Díez, M.A.; Barriocanar, C.; Casal, M.D.; Parra, J.B.; Álvarez, R. Adición de coque de petróleo a mezclas coquizables. Modificación de la calidad del coque metalúrgico. Rev. Metal. 1995, 31, 235-241. [CrossRef]

39. Ruiz, O.; Romero-Palazón, E.; Díez, M.A.; Marsh, H. Co-carbonization of green petroleum cokes with Cortonwood coal: Influence on structure, reactivity and microstrength of resultant cokes. Fuel 1990, 69, 456-459. [CrossRef]

(c) 2015 by the authors; licensee MDPI, Basel, Switzerland. This article is an open access article distributed under the terms and conditions of the Creative Commons by Attribution (CC-BY) license (http://creativecommons.org/licenses/by/4.0/). 